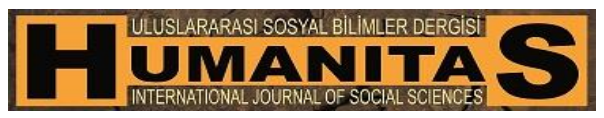

Humanitas, 2017; 5(9): 95-105

ISSN: 2147-088X

http://humanitas.nku.edu.tr

DOI: $\underline{10.20304 / \text { humanitas. } 318510}$

Araştırma-İnceleme

\title{
FONGOGO: A CASE STUDY ON THE USABILITY OF THE LOCAL CROWDFUNDING AND FUNDRAISING WEBSITES IN TURKEY
}

\begin{abstract}
Sezen KAYHAN ${ }^{1}$
Abstract: The contemporary success of the global online crowdfunding platforms; Kickstarter and Indiegogo inspired Turkish entrepreneurs to develop similar websites for the local use. The websites Fongogo, Crowdfon, Fonlabeni and Bi Ayda were founded to get the attention of the Turkish benefactors and angel investors. However, in this funding system where the website itself has crucial importance as the main tool of the crowdfunding experience, these local platforms couldn't reach the success of their predecessors. The reported issues showed that the failure of the local websites is linked to their usability problems. The aim of this research is to determine these usability problems and evaluate efficiency, effectiveness and satisfaction score of the most widely used Turkish crowdfunding website; Fongogo. In order to examine this, a quantitative usability test was carried out to reach a Single Usability Metric (SUM) with a sample of 14 Turkish users in two age segments between 20-40 and over 40. In addition to the tests, interviews with project owners and previous users were also conducted. The findings support that the usability problems affect the funding campaigns negatively and the website needs to be improved both for benefactors and project owners.
\end{abstract}

Keywords: Crowdfunding, Fundraising, Usability, Website, Turkey.

\section{FONGOGO: TÜRKIYYE'DEKİ YEREL KİTLESEL FONLAMA VE KAYNAK GELIŞTIRME WEB SITELERININ KULLANILABİLIRLIĞİ ÜZERİNE BİR VAKA ÇALIŞMASI}

Öz: Kickstarter ve Indiegogo gibi uluslar arası kitlesel fonlama web sitelerinin başarısı, Türkiye'deki yatırımcıları yerel kullanım için benzer siteler geliştirilmesi konusunda etkilemiştir. Fongogo, Crowdfon, Fonlabeni ve BiAyda web siteleri Türkiye'deki bağışçıların ve melek yatırımcıların ilgisini çekmek için kurulmuştur. Ancak web sitesinin kendisinin bağış yapmakta en temel araç olduğu bu fonlama sisteminde yerel platformlar uluslar arası öncülerinin başarısına ulaşamamıştır. Raporlanan durumların ortaya koyduğu şekilde, bu websitelerinin uluslar

${ }^{1}$ Koç Üniversitesi. skayhan15@ku.edu.tr 
Kayhan, S. (2017). Fongogo: A Case Study On The Usabılity Of The Local Crowd

Fundıng And Fundrassing Websites In Turkey. Humanitas, 5(9), 95-105

aras1 örneklere kıyasla başarısızlık nedeninin, web sitelerinin kullanılabilirlik sorunlarıyla bağlantılı olduğu görülmüsştür. $\mathrm{Bu}$ araştırmanın amacı belirtilen problemleri tespitetmek ve Türkiye'de en çok kullanılan kitlesel fonlama sitesi olan Fongogo'yu etkililik, verimlilik ve kullanıcı tatmini açısından değerlendirmektir. Bu amaçla yaşları 20-40 ve 40 üstü olmak üzere iki kesim halindeki 14 Türk kullanıcının katılımıyla Tek Kullanılabilirlik Ölçevi'ne ulaşmak için nicel bir kullanılabilirlik testi uygulanmıştır. Teste ek olarak proje sahipleri ve geçmiş kullanıcılar ile görüşmeler yapılmıştır. Bulgular, web sitesindeki kullanılabilirlik sorunlarının bağış kampanyalarını olumsuz etkilediğini ve bu sitelerin hem bağışçılar hem de proje sahipleri için geliştirilmesi gerektiğini ortaya koymuştur.

Anahtar Sözcükler: Kitlesel Fonlama, Kaynak Geliştirme, Kullanılabilirlik, Web Sitesi, Türkiye.

\section{Introduction}

Online crowdfunding is defined as the practice of raising capital in small amounts from a large group of people using Internet or social media. The monetary donations are given in exchange for a perk; a future service or product. Web technologies and online payment systems are used to facilitate transactions between funders and project owners. Online crowdfunding platforms like Kickstarter and Indiegogo provide opportunities for all entrepreneurs with internet access to pitch an idea to their social circles and to gather funding to realize their work. (Gerber, 2002)

Crowdfunding platforms depend on an online social community. Recently scholars of social sciences started to be interested in how to get such a community started, integrate and encourage. (Resnick and Kraut, 2012) The crowdfunding websites which present various projects in different categories such as art, environment, education, film, design, technology and games offer this opportunity to start an online social community for the benefit of the project owners.

Currently, there are more than 50 crowdfunding websites in the US, and they are experiencing an exponential growth in popularity. Kickstarter.com, which started in 2009, now has more than $\mathbf{5 7 , 0 0 0 , 0 0 0}$ pledged per month. (Happy Birthday Kickstarter, 2011)

In Turkey the crowdfunding platforms started to be used in 2011. Fongogo, with its 138 projects (in January 2016), is the most widely used crowdfunding website in Turkey. Crowdfon follows it with 103 projects and Fonlabeni with 86 projects. Another website Biayda was closed due to a series of organizational problems.

Fongogo uses an All-or-Nothing funding model for individuals, which means that if a funding goal is not reached, the funds are returned to the funder and creator receives no funds. For corporations it adopts the All\&More fundraising system in which creators can keep the money they raise even though their funding goals are not achieved. 
From 138 projects of Fongogo, only 40 of them reached their goal and 98 projects failed. Fongogo's success rate of $\% 23$ is far beyond its predecessor Kickstarter's success rate of \%43. Sinemasal which was supported by 240 individuals is Fongogo's highest funded project with 81.020 TL. (Tekeoğlu, 2015) The number of funders and funding amounts are quite low compare to Kickstarter and Indiegogo.

The reasons of this big difference between global and local websites can be listed as technological familiarity, website recognition and the most obvious one: the usability problems of the local websites. The relation between the usability of the crowdfunding website and the performance of the campaignis understudied. Recent researches about crowdfunding focus on various aspects like the dynamics of crowdfunding (Mollick, 2014), the effects of the price and competition on giving (Meer, 2014) and the role of investors in the crowdfunding market (Kim and Viswanathan, 2013). Some other articles examine how the design of the project effect the crowdfunding performance (Xiao, Tan, Dong, Qi andJiayin, 2014), how the creative ideas can accelerate the campaigns (KuppuswamyandBayus, 2013)or how the language used in the project effects the crowdfunding campaign (Mitra and Gilbert, 2014),but they do not focus on the effects of the usability of the websites. This study intends to show how the usability of the website is directly linked to the success of the online crowdfunding experience.

\section{Methodology}

For the analysis of the funding process of Fongogo, a multi-method methodology is used. The procedure consisted of a pre-test interview, the actual test which is recorded by the online desktop recording tool Screencast-o-Matic and a post-test survey. The findings were collected with the Usability Test Data Logger Tool 5.1 and the results were calculated by Single Usability Metric (SUM) Calculator.

In addition to the application of the actual tests for the first time users, the questionnaires for the previous users were also provided to compare the results. These previous users answered the questions about their past funding experience through Fongogo and the difficulties they had to deal through this process.

Finally the project owners were interviewed about their donation collecting process. The statements of the project owners were recorded as comparison criteria.

\section{Participants}

A total of 47 informants participated in the research. 14 participants at the core of the research were the first time users and they tested Fongogo in a test pattern provided to them. 39 participants were previous users who exclusively funded projects and they filled the questionnaires about their past experience. 4 of the informants were the creators of various projects and they explained their 
Kayhan, S. (2017). Fongogo: A Case Study On The Usabılity Of The Local Crowd

Fundıng And Fundraisıng Websites In Turkey. Humanitas, 5(9), 95-105

experiences through interviews. Informants equally ranged in two age segments: first group is formed by the ages between 20-40 and the second group was over 40.

Project type focused on film production. The reason of the selection of a specific field was to compare the experiences of users who are interested in the same subject. The computer and internet knowledge of the participants varied, yet familiarity with internet and social media was a selection criteria of participants.

\section{Test Procedure}

The test consisted of three stages; a pre-test interview, the actual test and a posttest survey.

\subsection{Pre-test Interview}

In this stage the participants were asked if they have ever heard or used a global or local crowdfunding platform. Their answers defined their familiarity with crowdfunding websites. They were also asked if they are familiar with online shopping to find out how secure they feel about using their credit cards on websites. Their familiarity with social media sites, online shopping and crowdfunding websites were scored with a scale from 1 to 10 . The results of the test were evaluated with the results of the pre-test interview.

\subsection{Actual Test}

The participants were asked to select a project and make a donation to the selected project on Fongogo. The main task was to make the donation and the sub-tasks were:

- Selecting a Project

- Registering to the site

- Signing-in

- Selecting a Perk

- Entering Credit Card Details

- Making Payment

- Receiving Confirmation

The tests were conducted in different locations with the same computer (PC). The participants were asked to think aloud during the test. Their voices and the desktop moves were recorded by Screencast-o-matic.

\subsection{Post-test survey}

After the test, the participants filled the survey with 12 questions about their experience. They were asked about the difficulty level of the task, their thoughts about the website and if they satisfied using Fongogo.The questions were as follows:

- On which device you used theFongogo website? 
Kayhan, S. (2017). Fongogo: A Case Study On The Usabılity Of The Local Crowd

Fundıng And Fundrassing Websites In Turkey. Humanitas, 5(9), 95-105

- Did you fund more than one project on Fongogo?

- Do you personally know the owners of the project that you funded?

- Could you succeed to donate in your first attempt?

- Did you have any problems during the process?

- If you had a problem, in which stage of the process you had it?

- Can you scale the difficulty of donating throughFongogo? (1 to 10)

- How long did it take for you to make a donation? (1 to 10)

- Are you satisfied using Fongogo? (1 to 10)

- Are you going to support a project throughFongogo in the future?

- Do you suggest Fongogo to your friends?

- What are your suggestions to improve Fongogo?

\subsection{Results}

The results were collected to find Single Usability Metric (SUM) which is defined as "a single, summated and standardized metric that encapsulates the majority of information in four common usability metrics". These four metrics are; task completion rates, average time on task, average number of errors and post-task satisfaction. These metrics evaluate the efficiency, effectiveness and satisfaction score of the tested material. (Sauro and Kindlund, 2005)

\subsubsection{Effectiveness (Completion Rate and Errors)}

6 out of 14 participants failed to complete the test. 6 of these failed participants were from the age segment over 40. Most of these participants said: "They did not understand how to make a donation and the site does not guide them to do it." For a long duration they tried to understand the system of the website and when they couldn't understand, they quitted.

The system does not allow users to make donations without an account. This is why every user should register to the site to make a donation. The registration form is not clear and 4 participants did not understand which "password" they need to use to sign in.

After registration and receiving e-mail confirmation, the system directs the users to the main page and not the page of the project. Most of the participants had difficulties memorizing which project they were going to donate. And also because the 'search engine' of the site does not work well, they couldn't find the project again. All of these complications resulted in confusion and increased the fail rate of the test. 
Kayhan, S. (2017). Fongogo: A Case Study On The Usabılity Of The Local Crowd

Fundıng And Fundrassing Websites In Turkey. Humanitas, 5(9), 95-105

Table 1: Measure: Completion Rate

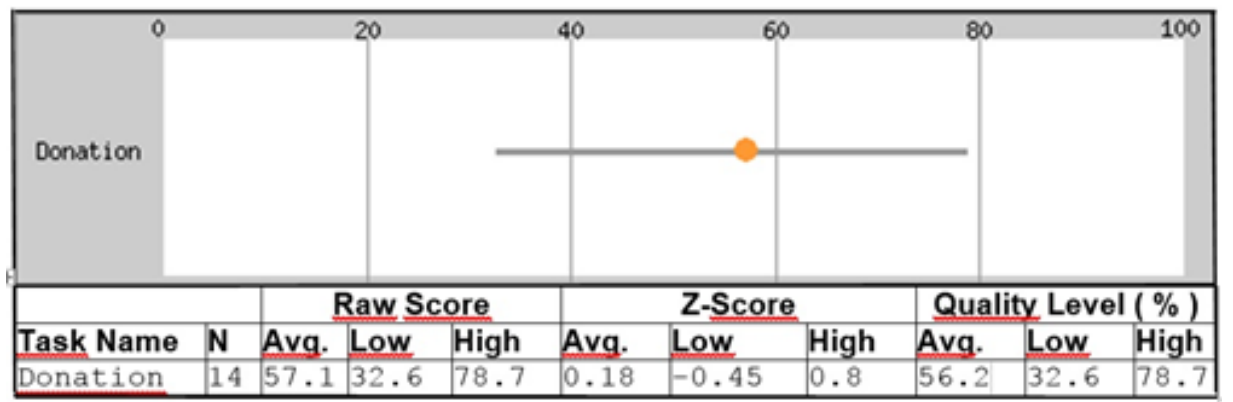

As the table shows the average completion rate of the test is $\% 56,2$ which means almost half of the users failed to complete the task.

The errors are calculated with the consideration of error opportunities. Sauro defines a task's error opportunity as the number of sub-tasks that a user must conform in order to complete a task error-free. According to this definition the number of error opportunities in Fongogotest was 7. Only 3 participants completed the test without any errors. All 12 participants had to deal with various error notifications.

Most of the errors belonged to "Sign-in" process. 9 out of 14 participants made errors while signing in. The most common errors were about the e-mail confirmations. Sometimes the system does not accept some e-mail addresses and says "this e-mail address is already registered", however it accepts the same address in third or fourth try of the user.

2 participants couldn't choose the perk. They said: "We did not understand that we had to choose the perk". And 1 participant did not receive confirmation after the test finished. So he couldn't be sure if he succeeded the test or not.

Table 2: Measure: Errors

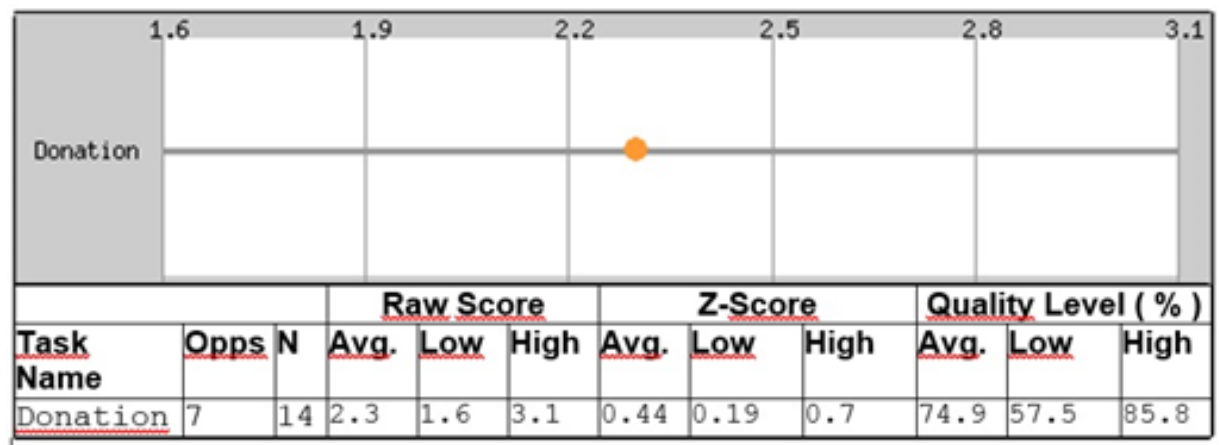

As the table shows the overall average error rate of the test is $\% 74.9$ which means major part of the users have to deal with errors in different stages of the process. 
Kayhan, S. (2017). Fongogo: A Case Study On The Usabılity Of The Local Crowd

Fundıng And Fundraisıng Websites In Turkey. Humanitas, 5(9), 95-105

\subsubsection{Efficiency (Time on Task)}

As mentioned in different researches, it is difficult to define the ideal time for a task. In this section a method suggested by Sauro is used to find the ideal time. According to Sauro there is a relation between ideal time and satisfaction scores. When the tasks take longer, post task satisfaction goes down. To find the ideal time these steps are followed:

-Removed times from failed tasks.

- Removed times where satisfaction scores are less than 5 (10 point scale).

- the 95th percentile of the remaining times to arrive at the specification limit. (Sauro, 2004)

A calculation with this method revealed the ideal time for Fongogotest as 8 minutes. 8 minutes give the users enough time to read the project briefly and proceed with the donation.

The Fongogo tests were conducted in various durations; the fastest was 3 minutes and 50 seconds, while the slowest continued for 26 minutes. The average of first age segment (20-40) is around 6 minutes and the average of second segment (over 40) is around 14 minutes. This clearly illustrates the difference between two age segments.

One of the participants said: "The design of the website is very confusing and it takes time to find a project on the site". Another participants said that even the "how it works" section of the site is very complicated and she needed time to understand it.

Table 3: Measure: Time

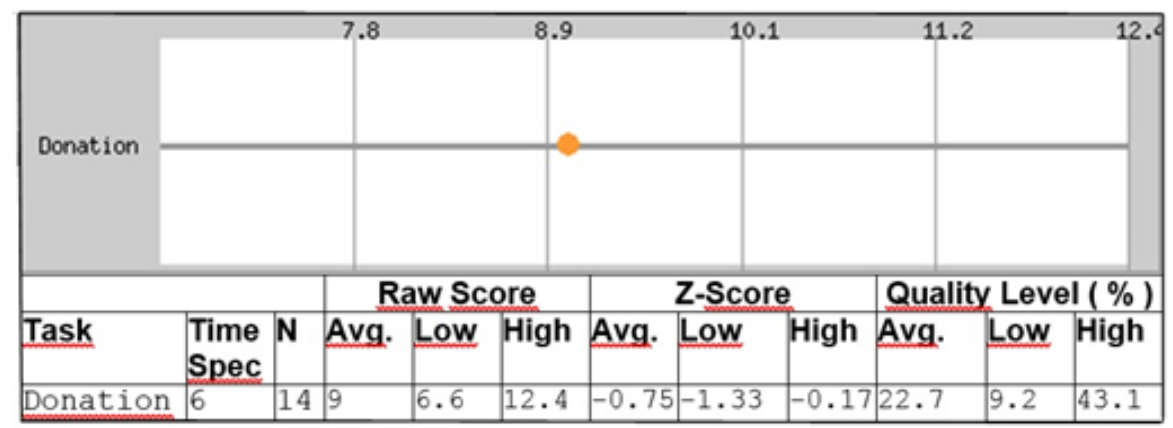

The average time rate of the test is $\% 22.5$ that shows most of the users complete the task in a longer duration than the ideal time.

\subsubsection{Satisfaction}

The satisfaction score is calculated as the average of the responses of overall ease, satisfaction and perceived task time. In the post-test survey the participants were asked:

- How difficult or easy was to complete the task on Fongogo?

- How satisfied are you with using Fongogo? 
Kayhan, S. (2017). Fongogo: A Case Study On The Usabılity Of The Local Crowd

Fundıng And Fundrassing Websites In Turkey. Humanitas, 5(9), 95-105

- How would you rate the amount of time it took to complete this task?

From a 10 point scale the average of overall ease is 4 points, perceived time is 6.2 points and satisfaction score is 5.3 points. The overall satisfaction rate of the test is $\% 41,7$ which shows more than half of the participants are not satisfied with using Fongogo.

\subsection{Single Usability Metric (SUM)}

By averaging together a standardized version of completion rates, task-times, task-level satisfaction and errors you generate a Single Usability Metric (SUM) which summarizes the majority of information in all four measures. (Sauro and Kindlund, 2005)

The average of all four measures in Fongogo test is calculated with the help of the SUM Calculator which is an online excel based calculator provided by www.measuringu.com.

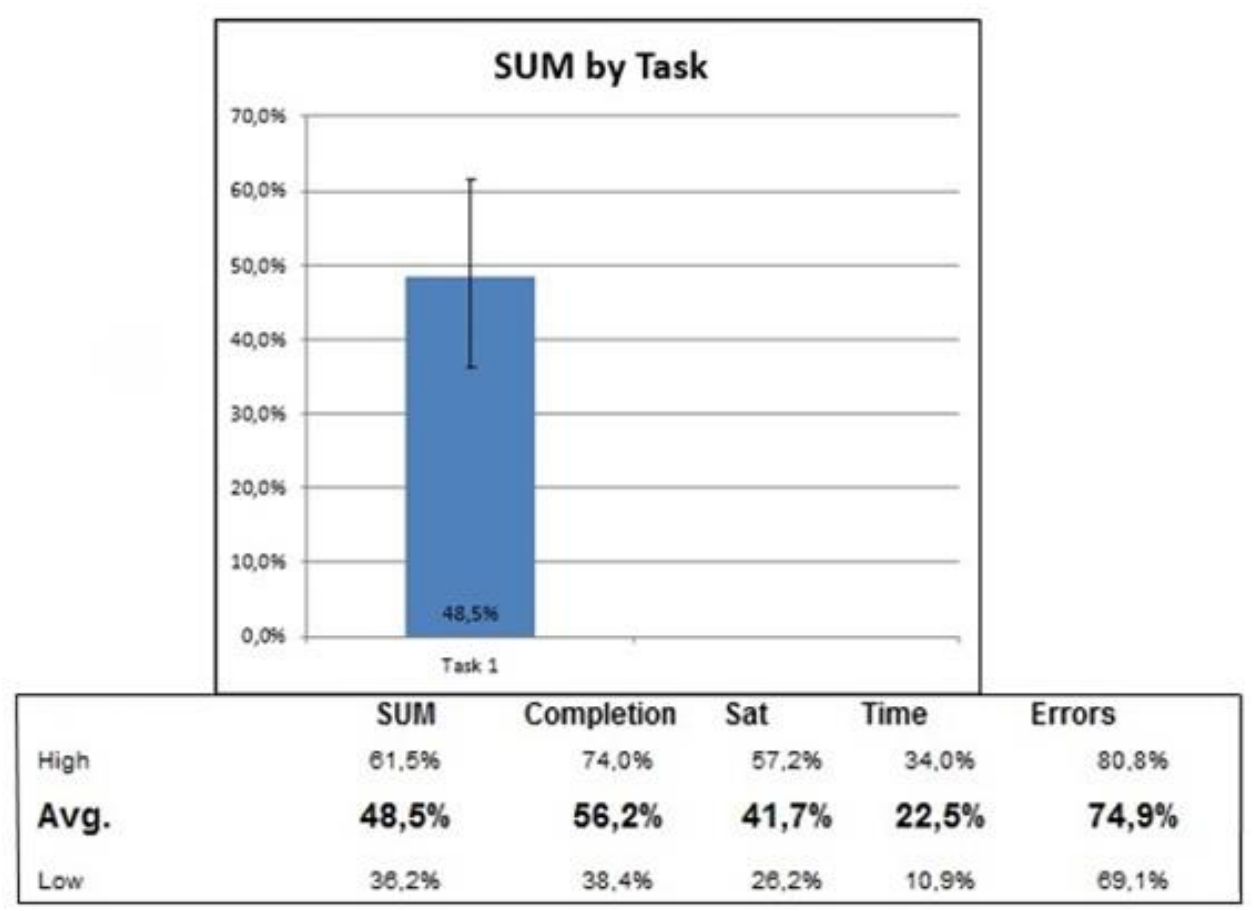

Figure 1. Single Usability Metric of FongogoTest

As the graph (Figure 1) shows the SUM score of Fongogo test is \%48,5 which clearly illustrates how the failure of the website is directly linked to its usability problems.

\subsection{Questionnaires for Previous Users}

The actual test is supported with the questionnaires sent to the previous users of Fongogo. The results of the test and the questionnaires were very close. In these 
questionnaires the previous users were asked if they had a problem during their donation process, if they are satisfied with using Fongogo and if they have suggestions to improve the website.

39 previous users participated in this survey. As the results show 18 of these 39 participants finished the process error free. Other 21 participants had problems in different phases of their donations. 11 of them made errors when signing-in, 3 of them had problems in selecting a perk, 4 users couldn't make the payment with their credit cards in their first try and 3 users did not receive confirmation after they finished.

The suggestions of the previous users are as follows:

- The site does not work on mobile phones and tablets or on Internet explorer. It should be available

on different devices.

- There are so many technical problems on the site which makes the process very difficult. The

technical problems need to be solved

- The opening page of the website is really complicated and it should be simplified.

- Sign-in process need to be easier, it takes a lot of time to sign-in.

\subsection{Interviews with Project Owners}

The interviews with project owners also supported the arguments of the research. The 4 project owners agreed that the usability problems of the website decreased the funding amount of their projects. They all expected to get more support from funders but couldn't receive it because of technical problems.

"We decided to open our project on Fongogo instead of Kickstarter because the site is in Turkish and we thought it would be easier for our supporters. But we were mistaken, it is more difficult than the English sites" one of the project owners said.

Another owner commented as "All or Nothing method was also really challenging because you need to reach your goal in order to collect the donations. If you cannot reach your goal, you cannot get other donations. And reaching the goal is very difficult with these technical problems."

The suggestions of the project owners are as follows:

- The website should be simplified and signing-in should be easier.

- The website is only in Turkish, there should be an option for English for foreign users.

- There is no virtual credit card option for payments, it needs to be added.

- All or Nothing method needs to be changed, there can be a minimum limit to withdraw other donations. 
Kayhan, S. (2017). Fongogo: A Case Study On The Usabılity Of The Local Crowd

Fundıng And Fundrassing Websites In Turkey. Humanitas, 5(9), 95-105

\section{Conclusion}

Local crowdfunding websites have an increasing importance in Turkey and many art, education and social responsibility projects started to be funded through the fundraising campaigns. The usability of the crowdfunding websites has crucial importance for the improvement of such independent projects. As this research points out the usability problems of the local crowdfunding websites have visible effects on crowdfunding campaigns.

Fongogo scored below average points for all four measurements related to efficiency, effectiveness and satisfaction. The Single Usability Metric (SUM) proved that the site has serious usability problems. Especially users over 40 are having difficulties understanding and using the website. Most of the users had problem in 'sign-in' process and couldn't create an account. The main menu and sub-menus are very confusing and not clear for navigation. The error rate is very high and the technical problems result many users to give up before finishing the donation process.Some other users who do not have technical problems, have security concerns because the system does not accept virtual credit cards. And some users who did not have any problems during donation, did not receive any confirmation e-mail, thus couldn't be sure if they succeeded or not.

The results of this research show that the design of the site needs to be reviewed, sign-in process and the steps of donation should be simplified and the transaction options need to be diversified with virtual credit card options in order the users to feel secure. The efficiency and effectiveness of the website can be increased with these interventions and the satisfaction score will raise imminently.

\section{References}

Gerber, E.M, Hui, J.S. andKuo, P.Y.(2012). Crowdfunding: Why People Are Motivated to Post and Fund Projects on Crowdfunding Platforms. ACM Conference on Computer Supported Cooperative Work. 11-15 February 2012.

Kim K. and Viswanathan S.(2013). The Experts in the Crowd: The Role of Reputable Investors in a Crowdfunding Market”. SSRN Electronic Journal: http://ssrn.com/abstract=2258243.

Kuppuswamy, V. andBayus, B.L.(2013). Crowdfunding Creative Ideas: The Dynamics of Project Backers in Kickstarter. SSRN Electronic Journal.

Meer, J. (2014). Effects of the Price of Charitable Giving: Evidence from an Online Crowdfunding Platform. Journal of Economic Behavior \& Organization 103: 113-124.

Mitra, T. and Gilbert, E. (2014) The Language That Gets People To Give: Phrases That Predict Success on Kickstarter. Proceedings of the 17th 
Kayhan, S. (2017). Fongogo: A Case Study On The Usabılity Of The Local Crowd

Fundıng And Fundraisıng Websites In Turkey. Humanitas, 5(9), 95-105

ACM Conference on Computer supported cooperative work \& social computing: 49-61.

Mollick, E. (2014). The Dynamics of Crowdfunding: An Exploratory Study. Journal of Business Venturing 29: 1-16.

"Happy Birthday Kickstarter!" (2011)TheKickstarter Blog - Kickstarter. (Online).Available: http://www.kickstarter.com/blog/hppy-birthdaykickstarter. (Retrieved: 2 Jan 2016).

Resnick, P. and Kraut, R. (2 qa011). Introduction. In Evidence-based Social Design: Mining Social Sciences to Build Online Communities. (pp 120). Cambridge: MIT Press.

Sauro, J. And Kindlund, E.(2005). A Method to Standardize Usability Metrics Into a Single Score. In CHI '05 Proceedings of the SIGCHI Conference on Human Factors in Computing Systems, 401-409.

Sauro, J. (2004). How long should a task take? Identifying Spec Limits for Task Times in Usability Tests. Retrieved January 1, 2016, from Measuring Usability Web site: http://measuringusability.com/time_specs.htm

Tekeoğlu, N.(2015). KitleselFonlamaileAlternatif Film Finansmanı Oluşturma ve Bir Film Analizi: Sıradışı İnsanlar. International Journal of Social Science 38: 295-302.

Xiao, S, Tan. X, Dong. M. and Qi, Jiayin. (2014). How to Design Your Project in the Online Crowdfunding Market. Proceedings of the Thirty Fifth International Conference on Information Systems, Auckland. 